\title{
PW01-022 - Dissociation between CRP and SAA in FMF
}

\author{
K Stankovic Stojanovic ${ }^{\text {* }}$, V Hentgen², S Georgin-Lavialle', S Fellahi ${ }^{3}$, I Jeru ${ }^{4}$ S Amselem ${ }^{4}$, J-P Bastard ${ }^{3}$, G Grateau ${ }^{1}$ \\ From 7th Congress of International Society of Systemic Auto-Inflammatory Diseases (ISSAID) \\ Lausanne, Switerland. 22-26 May 2013
}

\section{Introduction}

An Israeli study previously showed that dissociation between normal C-reactive protein (CRP) and elevated serum amyloid A (SAA) could be observed in Familial Mediterranean fever (FMF). Considering that elevated SAA is predictive for AA amyloidosis, this study suggested that SAA could be a better tool in the diagnosis and therapeutic management of FMF.

\section{Objectives}

To analyze the dissociation between CRP and SAA in a large cohort of FMF adults and children in France.

\section{Methods}

CRP and SAA were systematically measured during the follow-up of consecutive attack-free FMF outpatients seen in a pediatric and an adult French reference center. Dissociations between CRP and SAA were defined by normal CRP $(<5 \mathrm{mg} / \mathrm{L})$ and elevated SAA (group A), or elevated CRP and normal SAA $(<10 \mathrm{mg} / \mathrm{L})$ (group B). Demographic data, genotype, clinical characteristics of FMF, and treatment were analyzed.

\section{Results}

274 samples from 219 patients were analysed. The cohort had a median age of 24 years old [interquartile 15-35], $54 \%$ were female. Ethnic origins were: $60 \%$ non-ashkenasi Jews, $1 \%$ ashkenasi Jews, $4 \%$ mixed, 9.5\% Arabs, 5\% Armenians, 5\% Turks, 3\% Lebanese or Syrians, 1\% Italians, $1 \%$ Portuguese or Spanish, $1 \%$ Caucasian. MEFV genotype was known in 181 patients (83\%): 63.5\% had 2 non-ambiguous mutations, $24 \%$ were simple heterozygous, $7 \%$ were compound heterozygous with one nonambiguous mutation and one polymorphism, $5.5 \%$ had no mutation. Six patients had amyloidosis. 181 patients

${ }^{1}$ Internal Medicine, APHP, Hôpital Tenon, Paris, France

Full list of author information is available at the end of the article
(83\%) were treated with colchicine, 3 patients with interleukin -1 inhibitor. Elevated SAA (median $=16.5 \mathrm{mg} / \mathrm{L}$ [13;31] while normal CRP was found in 21 samples $(13 \%$ samples of with normal CRP). Elevated CRP (median $=9 \mathrm{mg} / \mathrm{L}[7 ; 11])$ while normal SAA was found in 38 samples ( $22 \%$ samples of normal SAA). Age was significantly higher in group $\mathrm{B}$ comparing to group $\mathrm{A}$ or the group with no dissociation (33 years old versus 21 and 23 respectively, $\mathrm{p}=0.004)$. Colchicine dosage was significantly higher in group $\mathrm{B}$ comparing to the group with no dissociation $(1.05 \mathrm{mg} /$ day versus $1.34, \mathrm{p}=0.04)$. No statistical difference was found concerning genotype or Ethnic origin. Dissociation with high SAA and normal CRP was found in some patients with amyloidosis but the difference was not statistically different $(\mathrm{p}=0.08)$. Finally, for values of CRP above $30 \mathrm{mg} / \mathrm{L}$ (30-63mg/L), corresponding SAA values were 1.5 to 6 times higher (53-683).

\section{Conclusion}

Dissociation between SAA and CRP was not frequent in our study. Genotype and ethnic origin were not predictive for this dissociation.

\section{Disclosure of interest}

None declared

\section{Authors' details}

${ }^{1}$ Internal Medicine, APHP, Hôpital Tenon, Paris, France. ${ }^{2}$ Pediatrics, Hopital de Versailles, Le Chesnay, France. ${ }^{3}$ Biochemistry Laboratory, APHP, Hôpital Tenon, Paris, France. ${ }^{4}$ Genetic Laboratory, APHP, Hopital Trousseau, Paris, France.

Published: 8 November 2013

doi:10.1186/1546-0096-11-S1-A75

Cite this article as: Stojanovic et al:: PW01-022 - Dissociation between CRP and SAA in FMF. Pediatric Rheumatology 2013 11(Suppl 1):A75.
C Biomed Central

(c) 2013 Stojanovic et al; licensee BioMed Central Ltd. This is an Open Access article distributed under the terms of the Creative Commons Attribution License (http://creativecommons.org/licenses/by/2.0), which permits unrestricted use, distribution, and reproduction in any medium, provided the original work is properly cited. 